\title{
PENGEMBANGAN BAHAN AJAR BAHASA INDONESIA SD \\ BERBASIS KEWIRAUSAHAAN UNTUK MENUMBUHKAN JIWA ENTREPRENEURSHIP PADA GENERASI MUDA
}

\author{
Oleh : Muhammad Noor Ahsin ${ }^{1)}$ Nurul Rizka Arumsari ${ }^{2)}$ \\ PGSD FKIP Universitas Muria Kudus ${ }^{1,2)}$
}

\begin{abstract}
ABSTRAK
Penelitian ini bertujuan untuk mengembangkan bahan ajar bahasa Indonesia berbasis kewirausahaan, dan mengetahui kelayakan untuk siswa kelas IV Sekolah Dasar. Penelitian ini termasuk penelitian dan pengembangan.Penelitian ini didasarkan pada kurang tersedianya bahan ajar bahasa Indonesia berwawasan kewirausahaan.Tahapan yang digunakan diambil dari gagasan Borg dan Gall. Tahapan penelitian, meliputi: pengumpulan informasi awal, perencanaan, pengembangan format produksi awal, uji coba awal, revisi produk, uji coba lapangan, revisi produk, uji coba lapangan, revisi produk akhir, dan desiminasi serta implementasi. Validasi bahan ajar dinilai oleh dua validator.Berdasarkan analisis data uji ahli, diketahui bahwa bahan ajar yang dikembangkan berkategori baik dari aspek kelayakan isi, penyajian bahasa, dan kegrafikan karena persentasi lebih dari $76 \%$.Hasil uji coba lapangan diperoleh nilai siswa rata-rata 82. Jadi, berdasarkan hasil penelitian tersebut dapat disimpulkan bahwa bahan ajar bahasa Indonesia berbasis kewirausahaan layak digunakan dalam pembelajaran di sekolah Dasar kelas IV.
\end{abstract}

Kata Kunci: Pengembangan, bahan ajar, bahasa Indonesia, kewirausahaan

\section{PENDAHULUAN}

Dewasa ini, orientasi siswa dan bahkan mahasiswa kita setelah lulus berlomba-lomba untuk menjadi pegawai bukan sebagai pengusaha atau entrepreneurship. Secara budaya, status pegawai apapun jabatan yang disandangnya cenderung lebih mendapat pengakuan masyarakat.Tak heran, setiap kali ada penerimaan CPNS seperti sekarang ini selalu disambut antusias sarjana kita.Sementara, para pencari kerja rela berdesak-desakan dan antri membeli tiket di Bursa Tenaga Kerja sekadar mencari informasi lowongan kerja ditawarkan perusahaan swasta.Pendidikan kita berorientasi pencari kerja bukan pencipta lapangan pekerjaan.Banyak masyarkat yang berebut mendaftar CPNS daripada mendirikan usaha atau menjadi entrepreneurship.

Padahal, usaha yang ditopang jiwa entrepreneur (wirausaha) terbukti cukup tangguh menyangga ekonomi negeri ini dari kehancuran di saat krisis moneter.Mengingat fungsi strategisnya bagi ketahanan ekonomi nasional, upaya menanamkan jiwa entrepreneur sejak dini sangatlah penting untuk menciptakan generasi mandiri yang tangguh.(Putri Nur Fahmi, 2013). Sayangnya, budaya pendidikan di Indonesia kurang mendukung pengembangan jiwa kewirausahaan sehingga menghambat 
pelajar untuk mengembangkan daya kreativitasnya. Menurut BPS, Tingkat Pengangguran Terbuka (TPT) Februari 2015 sebesar 5,81 persen, sedangkan TPT Agustus 2014 (5,94 persen), dan meningkat dibandingkan Tingkat Pengangguran Terbuka (TPT) Februari 2014 $(5,70$ persen).

(https://www.bps.go.id,2016)

Dalam konteks itulah maka pengembangan bahan ajar materi pelajaranbahasa Indonesia yang berkaitan tentang kewirausahaan untuk menumbuhkan jiwa entrepreneurship pada anak usia dini khususnya siswa sekolah dasarperlu diterapkan. Materi ajar berbasis kewirausahaan ini diharapkan mampu mengubah paradigma kalangan terdidik yang cenderung menjadi pekerja agar memiliki motivasi untuk membuka lapangan kerja baru atau berwirausaha.

Pendidikan jiwa wirausaha di sekolah tidak selalu identik dengan berbisnis, namun lebih ditekankan dapat membentuk sikap seperti: pribadi mandiri, memiliki kecakapan hidup (life skill) dan melatih kepemimpinan (leadership) siswa di masa depan. Mandiri, siswa mendayagunakan potensi diri dan kreativitasnya untuk "menghasilkan" minimal mencukupi kebutuhan dirinya sendiri. Siswa pun cakap mengelola keuangan berkaitan hal-hal produktif, termasuk menjadi konsumen yang "pintar" tidak gampang terbujuk rayu iklan-iklan. Satu hal lagi mencetak seorang entrepreneur, bukan saja pemilik sekaligus direktur (pemimpin usaha). (Maryani Hadiriyanto, 2012).

$$
\text { Dalam Kompetensi Dasar (KD) }
$$
bahasa Indonesia Sekolah Dasar Kelas IV ada materi yang berkaitan dengan usaha atau kewirausahaan. Yaitu poin 2.3 Memiliki perilaku santun dan jujur tentangjenis-jenis usaha dan kegiatan ekonomi melaluipemanfaatan bahasa Indonesia dan 3.3 Menggali informasi dari teks wawancaratentang jenis-jenis usaha dan pekerjaan sertakegiatan ekonomi dan koperasi dengan bantuanguru dan teman dalam bahasa Indonesia lisandan tulis dengan memilih dan memilah kosakatabaku.

Kompetensi Dasar tersebut yang menjadi latar belakang pengembangan bahan ajar materi pelajaran bahasa Indonesia kelas IV SD yang berbasis kewirausahaan. Bila anak didik mulai sekolah dasar hingga perguruan tinggi diberikan materi kewirausahaan secara terintegrasi, niscaya generasi masa depan akan berparadigma kewirausahaan pula. Hal ini akan berdampak pada menurunnya tingkat ketergantungan generasi muda untuk mengandalkan lapangan pekerjaan yang disediakan oleh pemerintah, sehingga akan berdampak pula pada menurunnya angka pengangguran. 
Berdasarkan pemaparan tersebut maka peneliti tergerak untuk membuat pengembangan bahan ajar materi pelajaran bahasa Indonesia yang berbasis kewirausahaan. Tujuan pada penelitian ini yakni mampu memberikan pengembangan terbaru terhadap materi ajar bahasa Indonesia indonesia berbasis kewirausahaan untuk menumbuhkan jiwa entrepreneurship pada generasi muda terutama pada siswa di sekolah dasar.

Prastowo (2011) menyatakan pemahaman bahan ajar sebagai segala bahan (baik informasi, alat, maupun teks) yang disusun secara sistematis, yang menampilkan sosok utuh dari kompetensi yang dikuasai peserta didik dan digunakan dalam proses pembelajaran dengan tujuan perencanaan dan penelaahan implementasi pembelajaran.

Keterpurukan sebuah negara bukan hanya disebabkan oleh sumberdaya alam yang mulai menipis, krisis moneter, dan rata-rata pendapatan per kapita yang rendah.Akan tetapi, yang lebih penting lagi adalah disebabkan oleh sumberdaya manusia yang lemah dalam menangkal dan mengantisipasi krisis yang terjadi. (Santoso, 2014)

Entrepreneur adalah jawaban atas masalah pengangguran dan kemiskinan. Jawaban untuk menanggulangi kemiskinan dan pengangguran sekali lagi ditekankan oleh Ciputra (2009) adalah membangun kewirausahaan dalam populasi yang cukup sehingga sampai pada kondisi critical mass, dan kemudian didorong untuk mencapai momen inersia internal, yang membuat pertumbuhan ekonomi dan penciptaan kesejahteraan dapat berjalan mandiri atau otonom, tidak digerakkan atau ditarik dari luar, secara organic berjalan selaras dari dalam.

Dengan demikian, untuk penanggulangan kemiskinan dan pengangguran, utamanya kemiskinan sebagai akibat globalisasi, entrepreneur perlu dijadikan bangunan baru dalam arus besar teori ekonomi (Christian, 2013).

Peranan entrepreneurship terhadap kemajuan perekonomian sebuah bangsa pernah diteliti oleh Gwartney et. al(2013) yang menyimpulkan bahwa pendidikan entrepreneurship sebagai sebuah strategi penting untuk membangun masa depan bangsa.

Menurut Retno dan Trisnadi (2012) ada beberapa motif yang diyakini dapat menjadi faktor pendorong seseorang menekuni profesi wirausaha seperti kebebasandalam bertindak dan mengambil keputusan, penghasilan yang lebih tinggi, aktualisasi diri, dan kemandirian. Motifmotif tersebut menjadi pendorong mahasiswa untuk menekuni profesi sebagai wirausahawan di masa yang akan datang. 
Sebelum dilakukan penelitian tentang Pengembangan Bahan Ajar Bahasa Indonesia Berbasis Kewirausahan untuk Menumbuhkan Jiwa Entrepreneurship pada Generasi Muda telah dilakukan penelitian yang relevan dengan penelitian tersebut.

Putri Nur Fahmi (2013) dengan judul Pembelajaran Tematik Berbasis Bisnis Day sebagai Upaya Implementasi Kurikulum 2013 di SD. Penelitian ini membahas tentang pembelajaran tematik di Sekolah dasar berbasis bisnis Day. Atau bisnis harian.Hasil yang didapatkan dalam penelitian tersebut adalah pembelajaran tematik dengan melakukan eksplorasi atau basis bisnis harian sehingga pembelajaran hasilnya lebih menarik.Dengan memberikan pengalaman yang bermakna bagi mereka serta pembelajaran menjadi lebih menyenangkan.

\section{Dewi, Laksmi (2015) Meneliti} tentnag Model Pendidikan Karakter dan Kewirausahaan Berbasis Etnopedagogis di Sekolah Dasar Kampung Cikondang.Mimbar, Jurnal Sosial dan Pembangunan.Penelitian tersebut dilakukan di sekolah Dasar berkaitan dengan Model Pendidikan Karakter dan Kewirasahaan. Hasil penelitian Proses adaptasi nilai-nilai karakter dan kewirausahaan yang terdapat di kampung adat secara umum cukup banyak memiliki nilai-nilai budaya yang dapat diintegrasikan pada proses pembelajaran.

Beberapa penelitian yang telah dilakukan terkait model pendidikan karakter, bahan ajar, maupun model pendidikan kewirausahaan, pendidikan karakter dengan pendekatan komprehensif yang diintegrasikan terbukti efektif untuk meningkatkan pengamalan nilai-nilai target yang ingin dicapai, sekaligus juga meningkatkan hasil belajar Bahasa Indonesia, IPA, dan IPS (Zuchdi, dkk, 2010:11).

F. Putut Martin HB (2012) Meneliti tentang Pengembangan Bahan Ajar Science Entrepreneurship Berbasis hasil penelitian Untuk mendukung program kreativitas Mahasiswa. Pengembangan bahan ajar science entrepreunership dilakukan dengan mengintegrasikan hasil penelitian kewirausahaan. Validasi bahan ajar sebagai produk pengembangan akan dilakukan oleh pakar media pembelajaran IPA dan kewirausahaan, selanjutnya dilakukan uji lapangan dengan menggunakan bahan ajar dalam pembelajaran science entrepreunership. Perbedaan Penelitian yaitu penelitian Putut Martin dilakukan kepada mahasiswa, sedangkan penulis melakukan penelitian kepada para siswa Sekolah Dasar di Kudus. 


\section{METODE PENELITIAN}

Pendekatan yang digunakan pada penelitian ini menggunakan pendekatan metode penelitian dan pengembangan (research and development/R\&D). Menurut Sugiyono (2011: 407) metode penelitian dan pengembangan adalah metode penelitian yang digunakan untuk menghasilkan produk tertentu, dan menguji keefektifan produk tersebut.Penelitian ini dilaksanakan di SD Muhammadiyyah 1 Kudus dan SD 2 Besito.Data diperoleh dengan observasi, wawancara, dan angket.Hasilnya kemudian dianalisis.

Model pnelitian dan pengembangan bahan ajar ini menggunakan gagasan Borg dan Gall dengan tahapan diantaranya Penelitian dan pengumpulan informasi awal, perencanaan, pengembangan format produksi awal, uji coba awal, revisi produk, uji coba lapangan, revisi produk, uji coba lapangan, revisi produk ahir, dan desiminasi dan implementasi. Karena keterbatasan waktu penelitian, penelitian ini belum sampai pada desiminasi dan implementasi.Penelitian yang dilakukan ini hanya menghasilkan revisi produk akhir.

Kualitas bahan ajar bahasa Indonesia berwawasan kewirausahaan yang dikembangkan ini diperoleh dari penilaian oleh ahli materi dan bahasa dari
Fakultas Keguruan dan Ilmu Pendidikan Universitas Muria Kudus dengan bidang keahlian pembelajaran bahasa Indonesia, Ristiyani, M.Pd. dan ahli media dan ekonomi dari Fakultas Ekonomi Universitas Muria Kudus Zaenal Afifi, SE., M.Si. kriteria penghitungan data menggunakan skala likert.

Analisis Validasi Produk oleh Ahli Ma-teri dan Ahli Pembelajaran.Penilaian oleh para ahli dan responden dilakukan dengan pengklasifikasian interval empat.Data yang diperoleh dari masingmasing aspek yang telah dikembangkan menjadi indikator-indikator ke-mudian dianalisis.Rata-rata skor terakhir yang diperoleh dikonversikan menjadi data kualitatif untuk mengetahui tingkat kelayakan tiap aspek.(Sudiati, 2017).

Langkah - langkah dalam menganalisis validasi produk oleh ahli materi dan ahli pembelajaran adalah sebagai berikut.

a. Data kuantitatif dari skala likert pada lembar validasi ahli diubah menjadi data kualitatif

b. Menjumlahkan skor untuk setiap butir aspek penilaian dari seluruh subjek penelitian.

c. Menghitung skor total rata-rata dari setiap aspek dengan rumus

$$
\bar{x}=\frac{\sum x}{n}
$$


d. Mengubah skor rata-rata menjadi nilai berupa kategori berdasarkan pedo-man konversi skala empat sebagai berikut. (Sudiati, 2017)

Tabel 1. Konversi Data Kuantitatif menjadi Data Kualitatif

\begin{tabular}{clccc}
\hline No. & \multicolumn{1}{c}{$\begin{array}{c}\text { Rentang } \\
\text { Skor }\end{array}$} & Nilai & Persentase & Kategori \\
\hline 1. & $\bar{x}>3,4$ & A & $76 \%-100 \%$ & Baik \\
2. & $2,6<\bar{x} \leq 3,4$ & B & $52 \%-76 \%$ & Cukup \\
3. & $1,8 \leq \bar{x} \leq 2,6$ & C & $36 \%-52 \%$ & Kurang \\
4. & $\bar{x} \leq 1,8$ & D & $0 \%-36 \%$ & Tidak Baik \\
\hline
\end{tabular}

\section{Keterangan:}

Presentase keidealan tiap aspek $=$

$$
\frac{\sum \text { skor rata-rata }}{\sum \text { skor maksimal tiap aspek }} \times 100 \%
$$

Presentase keidealan keseluruhan $=$ $\frac{\sum \text { skor rata-ratakeseluruhan }}{\sum \text { skor maksimal keseluruhan }} \times 100 \%$

Dalam penelitian pengembangan bahan ajar ini, nilai kelayakan produk ditentukan dengan nilai minimal adalah “B” yaitu kategori “cukup".

\section{HASIL DAN PEMBAHASAN}

Penelitian yang dilakukan ini terdiri atas beberapa tahap pengembangan. Diantaranya tahap penelitian dan pengumpulan informasi awal, tahap perencanaan, tahap pengembangan format produksi awal, tahap uji coba awal, tahap revisi produk, tahap uji coba lapangan, tahap revisi produk, tahap uji lapangan, tahap revisi produk akhir, dan desimenasi dan implementasi. Penelitian dan pengumpulan informasi melalui observasi dan wawancara kelas. Berdasarkan observasi dan wawancara siswa diperoleh data bahwa pembelajaran bahasa Indonesia memang ada penekanan kegiatan tentang kewirausahaan. Tapi materi yang diajarkan dari buku masih kurang lengkap kaitannya dengan melatih kewirausahaan siswa.Banyak siswa juga tertarik dengan kewirausahaan tapi masih bingung contoh nyata tentang kegiatan dan profesi kewirausahaan yang ada di masyarakat.Materi bahasa Indonesia yang berkaitan dengan kewirausahaan juga sangat sedikit.

Pertama, tahappengumpulan informasi awal atau analisis kebutuhan dilakukan untuk mendapatkan informasi mengenai mengenai kebutuhan bahan ajar bahasa Indonesia yang berwawasan kewirausahaan. Data yang didapatkan diperoleh dengan melakukan wawancara kepada guru kelas IV dan siswa di SD Muhammadiyah 1 Kudus.Hasil wawancara menunjukan bahwa guru yang mengajar menyadari pentingnya pendidikan kewirausahaan pada generasi muda khususnya di SD. Siswa juga belum banyak memahami tentang jenis pekerjaan yang berkaitan dengan kewirausahaan. Untuk memberantas kemiskinan adalah dengan pendidikan dan bekal ilmu kewirausahaan sejak usia dini. Karena usia dini merupakan saat yang paling tepat 
untuk menanamkan pengetahuan tentang kewirausahaan. Dengan demikian, suatu pembelajaran yang dapat mengakomodasi pendidikan kewirausahaan dalam kelas menjadi suatu hal yang harus dipikirkan dan diberi perhatian lebih oleh guru.

Dalam kenyataannya, guru mengatakan bahwa pembelajaran bahasa Indonesia berbasis atau berwawasan kewirausahaan dalam pembelajaran bahasa Indonesia memang tidak mudah. Di kelas IV memang ada KD yang menerangkan tentang profesi pekerjaan dan kegiatan ekonomi.Guru mengaku mengalami kesulitan apabila akan mengembangkan bahan ajar tersebut secara mandiri. Kesulitan ini ada dikarenakan dalam pengembangan bahan ajar berwawasan kewirausahaan guru harus memahami tentang entrepreneurship.Para guru mengungkapkan bahwa belum tersedianya bahan ajar yang dapat mengakomodasi pendidikan kewirausahaan dan mampu mengaktifkan siswa juga menjadi alasan kesulitan guru dalam mengintegrasikan pendidikan kewirausahaan dalam pembelajaran bahasa Indonesia.Oleh karena itu, para guru membutuhkan suatu bahan ajar bahasa Indonesia yang berwawasan kewirausahaan. Bahan ajar yang dibutuhkan juga diharapkan mampu membekali wawasan entrepreneurship bagi generasi muda terutama siswa sekolah dasar.
Kedua, perencanaan yaitu dilakukan dengan kegiatan merencanakan pembuatan bahan ajar berdasarkan informasi yang diperoleh di SD Muhammadiyah 1 Kudus.Pada tahap ini dilakukan pula pretes. Pretes berisi pertanyaan-pertanyaan tentang tentang jenis-jenis usaha dan kegiatan ekonomi melalui pemanfaatan bahasa Indonesia, jenis-jenis usaha dan pekerjaan serta kegiatan ekonomi dan koperasi .Ketiga, pengembangan produk. Tahap ini dilakukan dengan draf pengujiannaskah bahankepada dua validator, yaitu validator ahli pembelajaran bahasa Indonesia dari FKIP UMK dan validator desain grafis dan pakar ekonomi dari Fakultas ekonomi UMK.

Keempat, uji coba tahap awal. Naskah bahan ajar bahasa Indonesia berwawasan kewirausahaan yang telah dinilai validator diujicobakan kepadasiswa. Uji coba awal menghasilkan beberapa poin penting yaitu: (1) hasil wawancara kepada guru kelas tentang bahan ajar bahasa Indonesia berwawasan kewirausahaan; (2) observasi yang dilakukan oleh pengamat tentang kondisi pembelajaran; dan 3) angket siswa yang berisi tentang pertanyaan yang berkaitan tentang bahan ajar. Uji coba awal diujicobakan kepada siswa kelas IV .Kelima, revisi 
produk, yaitu memperbaiki draf berdasarkan hasil uji coba awal.Keenam, dilakukan uji coba terbatas ini menghasilkan data kuantitatif dari hasil belajar siswa yaitu pemahaman siswa tentang jenis usaha di masyarakat dan pekerjaan public serta kegiatan-kegiatan ekonomi di masyarakat.

Ketujuh, revisi produk berupa perbaikan-perbaikan dengan berdasarkan hasil uji coba terbatas.Hal ini dilakukan dengan tujuan untuk menghasilkan produk bahan ajar untuk perbaikan pada tahap berikutnya.Kedelapan, uji lapangan di SD 2 Besito Kecamatan Gebog Kabupaten Kudus dengan melibatkan subjek penelitian, disertai wawancara, observasi, dan penyampaian angket yang telah diberikan.Kesembilan, yaitu revisi produk akhir,kegiatan revisi yang dikerjakan berdasarkan uji coba lapangan yang telah dilakukan di SD 2 Besito Kecamatan Gebog Kudus.

Berdasarkan kriteria tabel 1, buku bahan ajar bahasa Indonesia berbasis kewirausahaan pada kelas IV dikatakan baik karena persentasenya lebih dari 76 $\%$. Berdasarkan keterangan skor, kualitas bahan ajar bahasa Indonesia berwawasan kewirausahaan kelas IV dikatakan baik apabila skor lebih dari $76 \%$. Skor penilaian dua ahli yaitu $90 \%$ dan $82,5 \%$. Jadi hal itu dikatakan baik. 
Tabel 2. Validasi Ahli Materi 1 dan 2 pada Aspek tentang Kelayakan Bahasa

\begin{tabular}{clcc}
\hline \multirow{2}{*}{ No. } & \multicolumn{1}{c}{ Indikator Penilaian } & \multicolumn{2}{c}{ Skor } \\
\cline { 3 - 4 } & & $\begin{array}{c}\text { Ahli } \\
\text { Materi 1 }\end{array}$ & $\begin{array}{c}\text { Ahli } \\
\text { Materi 2 }\end{array}$ \\
\hline 1 & Kesesuaian dengan tingkat kecerdasan siswa & 4 & 4 \\
2 & Kesesuaian dengan tingkat perkembangan sosial emosional & 4 & 3 \\
3 & Keterpahaman pesan & 4 & 4 \\
4 & Kesesuaian dengan ilustrasi dan substansi materi & 3 & 3 \\
5 & Ketepatan tata bahasa & 4 & 3 \\
6 & Ketepatan ejaan & 4 & 3 \\
7 & Keutuhan makna dalam bab, sub bab, dan paragraf & 3 & 3 \\
8 & Ketertautan sub bab, paragraf, kalimat & 3 & 3 \\
9 & Konsistensi penggunaan istilah & 4 & 4 \\
10 & Ketepatan penulisan nama ilmiah/asing & 3 & 3 \\
\hline & $\quad$ Jumlah & 36 & 33 \\
& Skor Rata-Rata & 3.66667 & 3.3 \\
& Persentase & $90 \%$ & $82,5 \%$ \\
& Kategori & Baik & Baik \\
\hline
\end{tabular}

Tahapan perencanaan, saat dilaksanakan hasilnya menyatakan bahwa data lapangan berupa kurangnya pemahaman siswa tentang jenis-jenis usaha masyarakat dan pekerjaan publik serta kegiatan ekonomi.Hal itu dibuktikan saat waancara dan pemberian angket kepada siswa.Siswa banyak yang tidak tahu jenis usaha, bedanya wirausaha dan menjadi buruh kerja.Hal ini melandasari dikembangkan bahan ajar berwawasan kewirausahaan.Hasil Pretes menunjukkan hanya 8 siswa yang lulus KKM.Siasanya 13 siswa tidak lulus KKM.Setelah dilakukan penilaian ahli, buku termasuk kategori baik karena rata-rata skor di atas $76 \%$.Untuk mendapatkan hasil yang lebih baik, maka bahan ajar dilakukan revisi berdasarkan saran dan komentar dari masing-masing ahli.Salah satunya adalah cover. Cover semua menggunakan gambar dua orang putra putri berkerdung dan berpeci, atas saran ahli diminta mengganti siswa yang memakai pakaian merah putih supaya kelihatan nasionalismenya. 


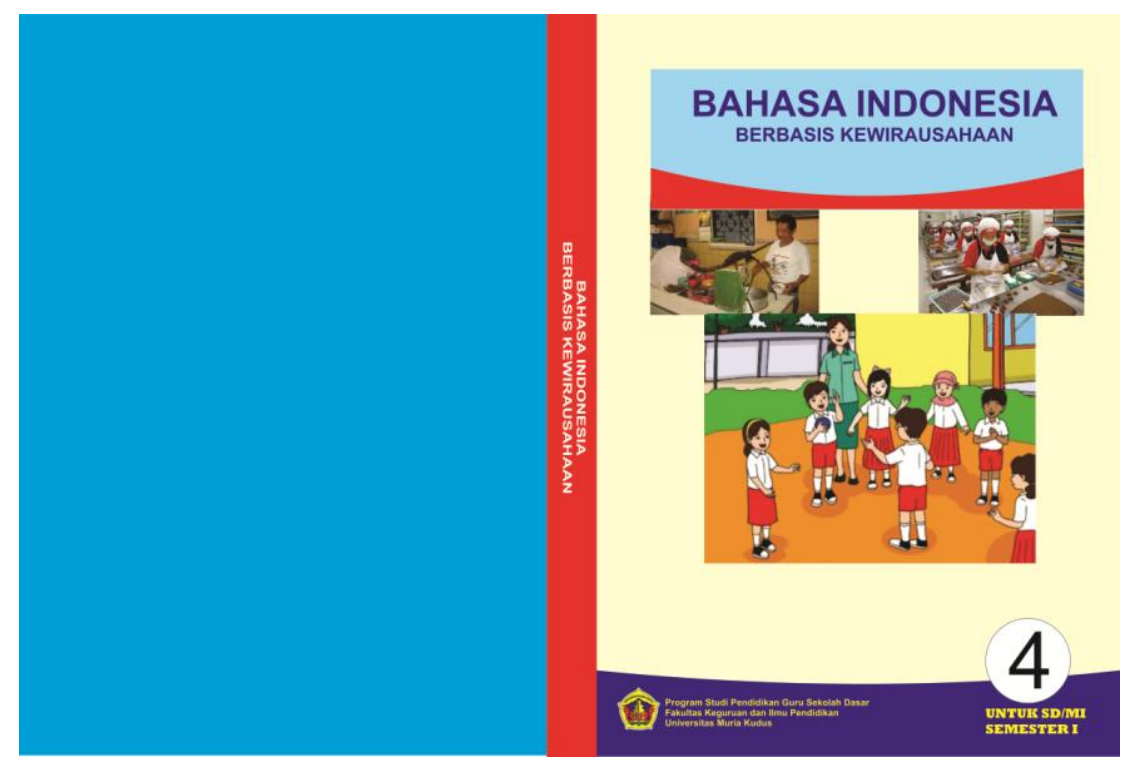

Gambar 1. Cover Bahan Ajar Bahasa Indonesia

Dalam penilaian wawancara, observasi dan angket telah membuktikan bahwa bahan ajar yang telah dibuat sudah layak diujicobakan.Namun karena ada beberapa kesalahan seperti gambar kurang jelas, salah ketik, kurang rapi maka buku ajar dilakukan revisi kembali pada tahap uji coba lapangan di sekolah Dasar kelas IV. Berdasarkan analisis likert, dapat disimpulkan bajwa hasil belajar bidang studi bahasa Indonesia Kompetensi Dasar (KD) Bahasa Indonesia kelas IV pertama Memiliki perilaku santun dan jujur tentangjenis-jenis usaha dan kegiatan ekonomi melaluipemanfaatan bahasa Indonesia. Kedua menggali informasi dari teks wawancaratentang jenis-jenis usaha dan pekerjaan sertakegiatan ekonomi dan koperasi dengan bantuanguru dan teman dalam bahasa Indonesia lisandan tulis dengan memilih dan memilah kosakatabaku, hasilnya baik menurut pendeskripsian skala likert karena rata-rata- nilai kelas terletak pada interval 77-100.

Berdasarkan hasil wawancara dengan guru kelas IV SD Muhammadiyah 1 Kudus, bahan ajar dinyatakan baik dan memeiliki manfaat positif.Mengenai hasil observasi juga menyatakan hasil yang bagus.Meskipun demikian, ada beberapa siswa yang masih kurang paham tentang jenis-jenis usaha dan pekerjaan secara mendetail.Hasil angket menunjukkan bahwa siswa menilai baik terhadap buku ajar yang berbasis atau berwawasan kewirausahaan meskipun di pembelajaran IPS juga disinggung pula tentang pekerjaan. 
Dalam penelitian ini, untuk mengetahui tingkat kualitasbahan ajar bahasa Indonesia berwawasan kewirausahaan yang dikembangkan, maka dilakukan uji kualitas. Uji kualitas bahan ajar bahasa Indonesia berwawasan kewirausahaan untuk menumbuhkan jiwa entrepreneurship pada generasi muda melalui penilaian pakar. Para pakar meliputi: seorang ahli pembelajaran bahasa Indonesia dan seorang ahli desain grafis dan ahli ekonomi. Bahan ajar bahasa Indonesia berwawasan kewirausahaan dikembangkan dengam memberikan contoh-contoh yang kontekstual dan riil yang dekat dengan anak di Kudus. Seperti jenis usaha Jenang Kudus, Soto Kudus, Desain grafis, kue, usaha penerbitan buku, usaha peternakan, usaha perikanan dan sebagainya.

Tabel 3. Hasil Analisis kegrafikan bahan ajar

\begin{tabular}{lcc}
\hline \multirow{2}{*}{ Indikator Penilaian } & \multicolumn{2}{c}{ Skor } \\
\cline { 2 - 3 } & Ahli Materi 1 & Ahli Materi 2 \\
\hline Jumlah & $\mathbf{9 0 . 5 8 8 2}$ & $\mathbf{8 5 . 4 1 1 8}$ \\
Skor Rata-Rata & 3.58 & $\mathbf{3 . 4 1}$ \\
Persentase & $\mathbf{8 9 , 7 \%}$ & $\mathbf{8 5 , 2 \%}$ \\
Kategori & Baik & Baik \\
\hline
\end{tabular}

Berdasarkan tabel di atas menunjukkan bahwa kualitas grafik bahan ajar bahasa Indonesia meliputi ukuran sampul, tampilan sampul, ilustrasi, komposisi, tipografi dan sebagainya secara total berkualitas baik. Hal itu karena persentasenya lebih dari $76 \%$. Jadi dapat disimpulkan bahwa kualitas grafik bahan ajar bahasa Indonesia berwawasan kewirausahaan layak digunakan sebagai bahan ajar bahasa Indonesia pada kelas IV Sekolah Dasar.

\section{PENUTUP}

Berdasarkan hasil pembahasan dapat diambil simpulan bahwa bahan ajar materi pembelajaran bahasa Indonesia berwawasan atau berbasis kewirausahaan untuk menumbuhkan jiwa enrepreneurship pada generasi muda khususnya siswa kelas IV SD sudah layak dan memenuhi syarat untuk digunakan sebagai bahan ajar bahasa Indonesia untuk berperilaku santun dan mengetahui jenisjenis usaha masyarakat dan kegiatan ekonomi masyarakat melaluipemanfaatan bahasa Indonesia. Hal itu disebabkan oleh hasil penilaian ahli atau reviewer rata-rata 
menghasilkan persentase lebih dari $76 \%$.

Dengan demikian, dapat disimpulkan bahwa bahan ajar bahasa Indonesia berwawasan atau berbasis kewirausahaan layak digunakan sebagai bahan ajar di Sekolah Dasar.

\section{DAFTAR PUSTAKA}

Badan Pusat Statistilk. Diakses di https://www.bps.go.id/Brs/view/id /1139 pada 1 Juni 2016.

Ciputra, (2009). Quantum Leap. Jakarta: Elex Media Komputindo.

Christian, S. (2013). Penggalakan Entrepreneurship Sebagai Langkah Awal untuk Peningkatan Kemandirian Perekonomian Indonesia. Jurnal Entreprenenur dan Entrepreneurship. $\quad$ Volume: 2. Nomor 1. Hlm. 29-42. Surabaya: Universitas Ciputra.

Dewi, L., et al. (2015). Model Pendidikan Karakter dan Kewirausahaan Berbasis Etnopedagogis di Sekolah Dasar Kampung Cikondang. Jurnal Mimbar. Volumer 31.Nomor 2. Hlm. 399-408. Bandung: Universitas Islam Bandung (Unisba).

Fahmi, P.N. (2013). Pembelajaran Tematik Berbasis Bisnis Day sebagai Upaya Implementasi Kurikulum 2013 di SD. (Prosiding). Diunduh dari upgrismg.ac.id/index.php/pgsd/pgs d/ paper/ view/324/276) pada 30 Mei 2016.

Gwartney, J.D., et al. (2013). Economic: Private and Public Choice. (14 $\left.{ }^{\text {th }} \mathrm{ed}\right)$ International. New York: Cengage Learning.
Martin, F.P. (2012). Pengembangan Bahan Ajar Science Entrepreneurship Berbasis Hasil Penelitian untuk Mendukung Program Kreativitas Mahasiswa. Jurnal Penelitian Pendidikan. Volume 29.Nomor 2. Hlm. 101-108. Semarang: Universitas Negeri Semarang.

Maryani, H. (2012). MembangunBudaya Pendidikan Kewirausaan secara Terintegrasi.http://www.kompasian a.com(diunduh pada 1 Juni 2016).

Prastowo, A. (2011). Panduan Kreatif Membuat Bahan Ajar Inovatif. Yogyakarta: Diva Press.

Santoso, I. (2014). Masalah dan tantangan Pengembangan Kewirausahaan pada Kalangan Mahasiswa di Indonesia. Jurnal Inovasi dan Kewirausahaan.Volume 3. Nomor 3 Hlm. 203-207. Yogyakarta.Universitas Islam Indonesia.

Sudiati \& Nurhidayah. (2017). Pengembangan Bahan Ajar Membaca Pemahaman Berdasarkan Strategi Plan (Predict, Locate, Add, Note) Untuk Siswa Kelas VII. Jurnal LITERA; Vol 16, No 1. Yogyakarta: Universitas Negeri Yogyakarta.

Sugiyono. (2005). Memahami Penelitian Kualitatif. Bandung: Alfabeta.

Retno B.L., Trisnadi, W. (2012). Pengaruh Pendidikan Kewirausahaan Terhadap Minat Berwirausaha Mahasiswa di STIE MDP, STMIK MDP, dan STIE MUSI. Jurnal Ilmiah STIE MDP Vol. 1 No. 2 Maret 2012 hlmn.112-119.

Zuchdi, D., Prasetya, Z.K., Masruri, M.S. (2010). Pengembangan Model 
Pendidikan Karakter Terintegrasi dalam Pembelajaran Bidang Studi Di Sekolah Dasar. Jurnal: Cakrawala Pendidikan, Mei 2010,
Th. XXIX, Edisi Khusus Dies Natalis UNY. 